\title{
New Species \\ of Anaplecta BURMEISTER, 1838 (Blattaria) from Chiapas Amber, Mexico
}

\author{
Peter Barna
}

Slovak Academy of Sciences, Geological Institute; Dúbravská cesta 9, P.O. BOX 106, 84005 Bratislava 45, Slovakia; e-mail:peter.barna@savba.sk

(C) 2015 Authors. This is an open access publication, which can be used, distributed and reproduced in any medium according to the Creative Commons CC-BY 4.0 License requiring that the original work has been properly cited.

Order Blattaria (cockroaches) originated in Late Carboniferous (Brongniart 1885, Zhang et al. 2012) and during its evolution adapted to various environments gaining diverse morphological adaptations including diversification of orders Mantodea (mantises) and Isoptera (termites) during Late Jurrasic/Early Cretaceous (Vršanský 2002, Vršanský \& Aristov 2014). Generic composition of fossil cockroaches of Cenozoic era is considered modern since with two exceptions (Anisyutkin \& Gröhn 2012, Vršanský \& Labandeira 2015) it is identical with the generic composition of living species. A new species of genus Anaplecta from Simojovel amber (Mexico: Chiapas), represented by single specimen, is reported herein, coming from Mazantic Shale, stratigraphically positioned right above the Oligocene/Miocene boundary at $23 \mathrm{Ma}$ (Vega et al. 2009). Cockroach, less than $5 \mathrm{~mm}$ long, is characterised by slender body, prolonged mouthparts bearing long palpomeres with distinct flattened triangular terminal palpomere, large eyes, and long slender legs with distinctly long tibial spines. Some leg- and palp segments differ in dimensions on left side and right side of the body, indicating slight dextro-sinistral asymmetry (visualisation includes the first partial visual 3D extraction ). In contrast to Supella miocenica Vršanský et al. 2011, but in concordance with other Cenozoic amber species, the present cockroach does not show any significantly primitive characters. The genus Anaplecta is cosmopolitan and 10 species live also in Mexico including Chiapas today. The new species is only the second (Vršanský et al 2011; Ischnoptera Burmeister, 1838 reported by Solorzano-Kraemer 2007) cockroach described from this amber. In addition to indigenous genera mentioned above and those characteristic for America, the present found is the first Cenozoic American occurrence of a living cosmopolitan genus. Supella Shelford, 1911, although known from the Chiapas amber apparently went extinct in Americas and today it is still present in other continents.

\section{REFERENCES}

Brongniart C., 1885. Les Insectes fossiles des terrains primaires. Coup d'oeil rapide sur la faune entomologique des terrains paleozod'ques avec 5 planches en heliogravure. Bulletin de la Société des Amis des Sciences Naturelles de Rouen, 3, 21, 50-68.

Solórzano-Kraemer M.M.S., 2007. Systematic, palaeoecology, and palaeobiogeography of the insect fauna from Mexican amber. Paleontographica Abteilung A, 282, 1-6, 1-133.

Vega F.J.T., Nyborg T., Coutino M.A., Solé J. \& Hernández-Monzón O., 2009. Neogene Crustacea from southeastern Mexico. Bulletin of Mizunami Fossiil Museum, 35, 51-69.

Vršanský P., 2002. Origin and Early Evolution of Mantises. AMBA projekty, 6, 1, 16.

Vršanský P., Cifuentes-Ruiz P., Vidlička, L., Čiampor F.J. \& Vega, F.J., 2011. Afro-Asian cockroach from Chiapas amber and the lost Tertiary American entomofauna. Geologica Carpathica, 62, 5, 463-475. 
Vršanský P. \& Aristov D., 2014. Termites (Isoptera) from the Jurassic/Cretaceous boundary: Evidence for the longevity of their earliest genera. European Journal of Entomo$\log y, 111,1,137-141$.

Vršanský P. \& Labandeira C., 2015. Early-derived Eocene Cockroaches (Blattaria: Ectobiidae: Pseudophyllodromiinae, Blattelinae) from the Green River Formation,
Colorado, U.S.A. Proceedings of the Entomological Society of Washington [in press].

Zhang Z.J., Schneider J.W. \& Hong Y.Q., 2012. The most ancient roach (Blattida): A new genus and species from the earliest Late Carboniferous (Namurian) of China, with discussion on the phylomorphogeny of early blattids. Journal of Systematic Paleontology, 11, 1, 27-40. 